\title{
Managing Real Estate Exposure: An Empirical Analysis on Interest Rate Risk
}

\author{
Cem Berk \\ Istanbul Arel University, Istanbul, Turkey \\ Email: cemberk@arel.edu.tr
}

How to cite this paper: Berk, C. (2017). Managing Real Estate Exposure: An Empirical Analysis on Interest Rate Risk. Journal of Financial Risk Management, 6, 256-268. https://doi.org/10.4236/jfrm.2017.63019

Received: July 10, 2017

Accepted: August 13, 2017

Published: August 16, 2017

Copyright $\odot 2017$ by author and Scientific Research Publishing Inc. This work is licensed under the Creative Commons Attribution International License (CC BY 4.0).

http://creativecommons.org/licenses/by/4.0/

\begin{abstract}
Real estate is an illiquid investment with cyclical returns, so risk management techniques should be used for sustainable returns. The risk management techniques include asset based, portfolio, insurance and derivatives solutions. Asset based solutions include the risk character of the real estate, based on where it's located and how well it is developed. Some property such as foreclosure and those require maintenance is riskier than others. Portfolio solutions allow real estate companies to include real estate with different location and segments such as office and retail. Using this, the risk is limited to the systematic component, where asset based-idiosyncratic risk is tried to be reduced when included enough number of assets to the basket. The management should be capable of determining which risks taking and which to transfer. Some risks such as earthquake, fire, vehicle crush, terrorist activities are rare in nature but can cause severe damage when it takes place. The insurance policies can cover these events which most of the time are reinsured. In addition derivatives are available to hedge some of the risks. These can be traded on the market or over-the-counter. By using derivatives it is possible to hedge interest rate risk, inflation, currency risks, and property price changes. To hedge interest rate risk which is also studied in this paper, instruments such as cap, swap, and collar are available. The research is investigating the role of interest rate risk in the performance of real estate management companies. The variables used in this research are 30 years treasury yield, and exchange closing price for CBRE Group Inc., Colliers International Group, and Jones Lang LaSalle Incorporated. The data is daily for the period 16 June 2004 and 19 June 2015. The methods used are Johansen Cointegration and Granger Causality. The results of the study indicate there is a short-run and long-run relationship between interest rate and real estate management firm stock performance. In other words, interest rate fluctuation is a critical risk in performance of real estate management companies. In the paper, it is also discussed risk mitigation ideas for controlling this
\end{abstract}


and other risks that real estate management industry is exposed.

\section{Keywords}

Real Estate, Risk Management, Derivative Contracts, Interest Rate Risk, Cointegration, Granger Causality

\section{Introduction}

Real estate is an investment that has its own characteristics different than buying marketable securities. It is a relatively illiquid investment. This is because finding a reasonable offer for your property at market price may require some time or effort such as promoting or talking with real estate agencies. Therefore real estate investor will demand some additional liquidity premium over liquid assets. In addition the investors should be liquid to cover for daily costs-working capital.

The return on real estate has two main aspects. One is rental gain that is the annual income that you can get from renting your property if it is not owner occupied. The other income is capital appreciation which is the increase in the value of the property. The return potential and risk are higher for properties that require more effort such as distressed properties or those that need maintenance.

During the real estate development process an investor may buy the land, develop a project, get the necessary permits, and sell to the final user. All of these processes require some risks. Those who buy earlier need to have more risk and except more return. When you buy a land you need to make sure the land has a location that its value can appreciate with the future city plans. Developing property means taking opportunity cost of not developing other property such as building office instead of retail. Most of the time the investor has to decide which real estate segment provides more return and develop the project accordingly. This is done by an analysis of location and market by not only considering current market dynamics but also future expectations. One needs to make sure that the chosen alternative is the most appropriate for obtaining highest return.

One special kind of real estate investor is a real estate investment trust (REIT). These companies are listed on stock exchange so that they have the disclosure obligations for the exchange. Real estate investment trusts have a portfolio of assets most of which include real estate and instruments based on real estate. The portfolio is often diversified which means having more than one asset in a portfolio. The portfolio also needs appraisal for investors to compute net asset value based on market prices. This investment environment brings transparent transactions which bring discipline for the industry. In return, they are given certain privileges such as being exempt from corporate tax. 
Real estate investments require leverage, because of the capital intensive nature of the transactions. This is in the form of mortgages for residential property and commercial loan and other methods for commercial property. This requires the investor to obtain loans with low down payment which means high profit when there is a capital appreciation or high loss when there is depreciation.

Investors need to be aware of managing real estate risks. Real estate has cyclical returns meaning it leads to positive returns for some years but may lead also to sharp negative returns. The investors who bought for low prices have the potential to earn more in the future. Portfolio building is a way to mitigate the risk. This can be done by adding property in different cities and countries and different function such as residential and industrial.

The risk management may include transferring some risk such as buying insurance contracts.

Derivative markets are also developed to cover for most market based risks from interest rates to property prices. This is done by creating indices for real estate depending on function and location.

The remainder of this paper is organized as follows. In Section 2, some of the relevant recent works in the literature are given. Then the methodology is described in Section 3. The information on the variables and empirical study is given in Section 4. In Section 5, some of the implications of the results are discussed. In Section 6, the practical and policy contributions are discussed.

\section{Literature Review}

Real estate investment like other investments has some risks that need to be managed. One of the most fundamental risks is the change in price of real estate itself. Real estate historically has returns more than inflation if held long enough, however in times of recession, one might expect the prices to decrease which results loss of wealth in the portfolio. There are also portfolio risks. Some real estate portfolios are more focused, investing more in one type of real estate segment and location. There are also risks that are common to all types of portfolios. These risks are related to change in economic conditions and market. Interest rate risk is one of these risks.

The critical risk in real estate business is interest rate as in other industries. Rising interest rates would benefit to investors who already borrowed and would be worse for those who are to borrow yet. The most common types of interest rate hedge agreements are caps, swaps, and collars. Under a cap the borrower and lender agree on a maximum interest rate. If the interest rate goes above the maximum interest rate, the hedge provider pays borrower the difference in exchange for a one-time fee.

For swap contracts plain vanilla can help in real estate industry. In this type of agreement fixed interest rate is exchanged for variable interest rate (such as LIBOR or treasury interest). Any person who believe that interests will rise and borrowed variable, can swap variable interest for fixed interest using plain vanil- 
la swap contract. Collar agreement determines both minimum and maximum interest rates. Therefore if the market interest rate is above the contract maximum rate the hedge provider pays the difference. But when the interest rate is lower than the minimum set by the contract, the borrower pays the difference (Montgomery, 2005).

One of the important risks in the real estate business is the operating costs. The operating costs are often very high. The real estate market is also cyclical, meaning there may be sharp price fluctuations. The projections of real estate sales revenue when you invest in a property may not be realized. The business is often highly leveraged and there is no tax shelter benefit. This means that if you use your debt you will pay less corporate tax. This is not the case with REITs (Real Estate Investment Trusts) since they are often tax exempt. More debt needs more exposure to be hedged. But for more growth, one needs to invest and hedge its portfolio using derivative instruments.

Building a housing development requires land development and building. Pre-selling is an idea to sell the houses before they are completed. This reduces some of the cost of finance since the money received may be used in construction but this may mean lower revenue compared to the sales with finished products. The developer also hedges itself against market prices when it pre-sells (Buttimer \& Pattel, 2007).

Although interest rates and real estate prices may seem correlated there might be differences in tough economic situations. The real estate prices may even cover behavioral effects such as change in work or children. Homeowners typically use real estate derivatives to hedge against their risk of price fluctuation in the relevant index. Banks and other institutions with real estate exposure can more easily hedge their diversified portfolio using these instruments.

For hedging house price risks futures and options are available written on relevant indices such as Standard and Poor's Case-Shiller consisting of property of the region. This is available in the derivatives exchanges such as Chicago Mercantile Exchange (CME). For commercial property derivative s can be written on indices such as NCREIF.

Mortgage portfolio hedging needs to address not only default risk but also prepayment risk. A prepayment is any amount of payment that is more than the scheduled payment. Financial institutions may need to make a discount on the interest since they receive the money earlier. Moreover the market interest may be different than the interest on the date of issue of the loan. Borrowers will prepay when interest rates fall but this may mean loss for the banks since their cost of funding may exceed the payments received in this type of economic environment. To avoid this loss, some countries allow a prepayment penalty to be paid by borrower for banks to cover this loss. It is possible to hedge this portfolio but there are difficulties seeing the projected prepayment rate may be different than what is realized (Fabozzi et al., 2009).

The risks embedded in a commercial real estate are change in price of proper- 
ty, credit risk, interest rate risk, liquidity risk, country risk and legal risks. Property price risk includes location of real estate, rent revenue, cost of carry, rollover of mortgage contracts. Property prices grow stably for years but may suddenly fall in the event of market corrections or crisis. Therefore it is a fundamental risk for financial markets.

Commercial property derivatives are developed mainly in the United States and United Kingdom. The relatively undeveloped structure of these instruments may be partly contributed to the fact that much of the risks associated with real estate is also included in market risks. This is used to hedge against real estate risks and also can be synthetically included in portfolios of institutional investors to increase commercial property exposure.

There are two types of default for commercial properties. The first is the borrower's inability to payback principal and interest of the loan. This is also called term default and this could happen when property price falls behind loan value. This can be hedged by commercial property derivatives. The other default is called balloon default where the borrower is unable to refinance its balloon payment. The term balloon often represents the principal in a mortgage loan where the interest is paid for a number of years and the principal needs to be refinanced after this period. This is almost like originating a new loan at current market conditions. This loan has a risk of balloon default that needs to be computed. This may be due to change in economic situation or borrower's credit rating (Fabozzi et al., 2013).

Derivatives markets have experienced rapid growth among asset classes as a tool for risk management especially for financial institutions. The real estate derivatives can be listed in the exchange or over-the-counter between counterparties. (OTC) There can be an intermediary which can also serve as a dealer taking the opposite position of the investor. In more mature markets, dealers can constitute hedges with diversified portfolios.

The real estate derivatives practice also allows the inclusion of a swap, where both parties exchange their cash flows. A total return swap is a transaction where the investor receives (or pays) whatever the real estate index value (typically NCREIF for commercial real estate) and in return pays (or receives) fixed amount. The duration of the trade is typically 2 - 3 years and exchange occurs every quarter of the year. The difficulties with the index based derivatives are not all the real estate prices are revalued quarterly and appraised values tend to lag transaction prices (Fisher, 2005).

Risk management is gaining importance particularly in the time of financial crisis. The application is however limited for the real estate asset class compared to other industries. The real estate investor may need to investigate risks of individual real estate in addition to the portfolio risk due to the high investment required for the asset class. This can be done by assigning risk ratings for the assets.

Another application may be to benefit from Modern Portfolio Theory (MPT). 
This is done to benefit from diversification benefits of real estate portfolio. The real estate shows completely different character than marketable securities when it comes to the application of MPT. At least 400 - 500 real estate is needed to completely reduce to the market-systematic risk. There are also difficulties in the application of MPT namely immobility, heterogeneity, indivisibility, high transaction costs, and limited sustainability (Donner, 2010).

\section{Research Model}

In cointegration all the variables yt have a unit root, or in other words, yt is a stationary when differenced I(1) process, it is said to be cointegrated when a linear combination of them is stationary, that is if the regression produces an $\mathrm{I}(0)$ error term. Johansen and Juselius proposed two hypothesis tests to help determine $r$, the number of cointegrating vectors. They are:

1) Trace test: The null hypothesis is that there are $r$ or fewer cointegrating vectors in the system. The statistic is: $-T \sum \ln (1-a)$. To determine the number of cointegrating vectors, $r$, the sequence of null hypothesis $r=0, r \leq 1, r \leq 2, r \leq$ $(q-1)$. If $r \leq q$ is the first null accepted then we conclude that there are $r=q$ cointegrating vectors.

2) Maximal eigenvalue test: The null hypothesis of the test is that the number of cointegrating vectors is $r$ versus the alternative hypothesis that the number is $r$ +1 . The test statistic is $-T \sum \ln (1-a)$. To determine the number of cointegrating vectors, $r$, the sequence of null hypothesis $r=0, r=1, \cdots, r=p-1$. If $r=q$ is the first null accepted, then conclusion is that there are $r=q$ cointegrating vectors (Erdinc \& Milla, 2009).

The granger causality model on the other hand can be explained with the below formulation. When historical values of one series are useful in explaining another series, one Granger causes another (Baumohl \& Vyrost, 2010).

$$
\begin{aligned}
& I_{1}=a+\sum a I_{1}+\sum b I_{2}+e \\
& I_{2}=a+\sum a I_{2}+\sum b I_{1}+e
\end{aligned}
$$

\section{Data Analysis}

This research explores the relationship between three real estate management firms and 30 years treasury yield in U.S.A ("shortly named as "TY30" for this study). The variables used in this study are CBRE Group Inc. (CBG) stock closing price from NYSE (shortly named as "CBRE” for this study), Colliers International Group Inc. (CIGI) stock closing price from NASDAQ (shortly named as "COLLIERS" for this study) and Jones Lang LasSalle Incorporated (JLL) stock closing price from NYSE ("shortly named as "JLL" for this study). The data is daily for the period 16 June 2004 and 19 June 2015. This period was available when this research is first presented in a major international conference. The data is available for all stocks and treasury yield during the period. The total number of data is 2.775 . The graphical presentation of the data is given in Figure 1 . 
The research methodology requires the variables to be stationary to the same degree. Therefore the first tests are Augmented Dickey Fuller (ADF) and Philips Perron unit root tests. The test results are given in Table 1.

The variables will be modeled in VAR. But first Lag Order should be determined. In Table 2 lag order selection criteria is given. For the principle of parsimony $\operatorname{VAR}(1)$ is used.

The Table 3 is given below as a stability check for the VAR model.

Below is the VAR(1) model with coefficients substituted.

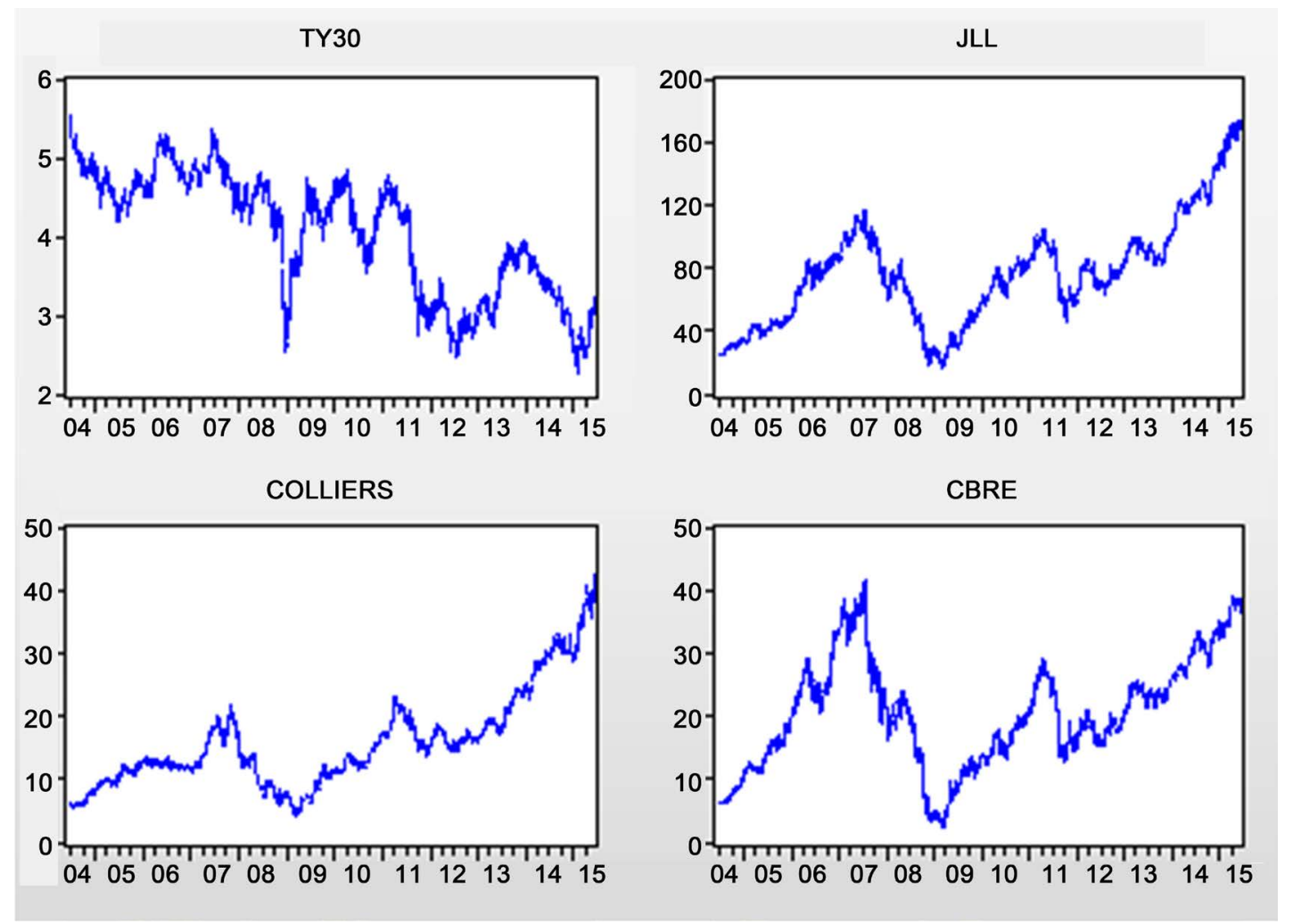

Figure 1. Graphical Presentation of Data.

Table 1. Results for unit root tests.

\begin{tabular}{ccccc}
\hline & ADF Test Statistic & Critical Value & PP Test Statistic & Critical Value \\
\hline TY30 & -3.3908 & -3.4114 & -3.2162 & -3.4114 \\
JLL & 1.5243 & -1.9409 & 1.7386 & -1.9409 \\
COLLIERS & 2.0398 & -1.9409 & 0.4864 & -1.9409 \\
CBRE & 0.3737 & -1.9409 & -2.3347 & -2.8645 \\
D(TY30) & -53.388 & -1.9409 & -53.515 & -1.9409 \\
D(JLL) & -56.115 & -1.9409 & -56.621 & -1.9409 \\
D(COLLIERS $)$ & -51.945 & -2.8624 & -52.063 & -2.8624 \\
D(CBRE) & -55.478 & -1.9409 & -55.555 & -1.9409 \\
\hline
\end{tabular}


Table 2. Lag order selection criteria.

VAR lag order selection criteria

Endogenous variables: D(TY30) D(JLL) D(COLLIERS) D(CBRE)

Exogenous variables: $\mathrm{C}$

Date: 06/25/15 Time: $22: 31$

Sample: 6/16/2004 6/19/2015

Included observations: 2764

\begin{tabular}{ccccccc}
\hline Lag & LogL & LR & FPE & AIC & SC & HQ \\
\hline 0 & -3159.406 & NA & 0.000116 & 2.289006 & 2.297579 & 2.292102 \\
1 & -3089.547 & 139.4652 & 0.000112 & 2.250034 & $2.292902^{\star}$ & $2.265518^{\star}$ \\
2 & -3072.976 & 33.03313 & $0.000111^{\star}$ & $2.249621^{\star}$ & 2.326784 & 2.277492 \\
3 & -3063.856 & 18.15550 & 0.000112 & 2.254599 & 2.366057 & 2.294857 \\
4 & -3053.041 & 21.49520 & 0.000112 & 2.258351 & 2.404104 & 2.310997 \\
5 & -3043.442 & 19.05267 & 0.000113 & 2.262983 & 2.443031 & 2.328016 \\
6 & -3026.670 & $33.24045^{\star}$ & 0.000113 & 2.262424 & 2.476767 & 2.339845 \\
7 & -3018.261 & 16.64170 & 0.000114 & 2.267917 & 2.516555 & 2.357725 \\
8 & -3008.480 & 19.32792 & 0.000114 & 2.272417 & 2.555350 & 2.374612 \\
\hline
\end{tabular}

${ }^{*}$ indicates lag order selected by the criterion; LR: sequential modified LR test statistic (each test at $5 \%$ level); FPE: Final prediction error; AIC: Akaike information criterion; SC: Schwarz information criterion; HQ: Hannan-Quinn information criterion.

Table 3. Stability test for VAR model.

Roots of characteristic polynomial

Endogenous variables: D(TY30) D(JLL) D(COLLIERS) D(CBRE)

Exogenous variables: $\mathrm{C}$

Lag specification: 11

Date: 06/25/15 Time: 22:37

\begin{tabular}{cc}
\hline Root & Modulus \\
\hline-0.102948 & 0.102948 \\
$-0.008518-0.053208 \mathrm{i}$ & 0.053886 \\
$-0.008518+0.053208 \mathrm{i}$ & 0.053886 \\
-0.044551 & 0.044551 \\
\hline
\end{tabular}

No root lies outside the unit circle. VAR satisfies the stability condition.

$$
\begin{aligned}
\mathrm{D}(\text { TY30 })= & -0.0364488634371 * \mathrm{D}(\mathrm{TY} 30(-1))+0.00339533077766 * \mathrm{D}(\mathrm{JLL}(-1)) \\
& +0.0104393577868 * \mathrm{D}(\operatorname{COLLIERS}(-1)) \\
& +0.00441707690148 * \mathrm{D}(\operatorname{CBRE}(-1))-0.00127395829336 \\
\mathrm{D}(\mathrm{JLL})= & 0.432287858167 * \mathrm{D}(\mathrm{TY} 30(-1))-0.0683583005087 * \mathrm{D}(\mathrm{JLL}(-1)) \\
- & 0.221009485116 * \mathrm{D}(\operatorname{COLLIERS}(-1)) \\
+ & 0.0527595792744 * \mathrm{D}(\operatorname{CBRE}(-1))+0.0590861661857
\end{aligned}
$$




$$
\begin{aligned}
& D(\text { COLLIERS })= 0.15889724 * D(T Y 30(-1))+0.00450494376351 * D(J L L(-1)) \\
&-0.0120372219648 * D(\text { COLLIERS }(-1)) \\
&+0.0341733825197 * D(C B R E(-1))+0.0109753809231 \\
& \mathrm{D}(\text { CBRE })=-0.00409501169524 * \mathrm{D}(\operatorname{TY} 30(-1))+0.00219996568092 * \mathrm{D}(\operatorname{JLL}(-1)) \\
&-0.0850427088929 * \mathrm{D}(\operatorname{COLLIERS}(-1)) \\
&-0.0476900049546 * \mathrm{D}(\operatorname{CBRE}(-1))+0.0124987137746
\end{aligned}
$$

Long-run relationship is studied with Cointegration analysis. The results are given in Table 4.

Table 4. Cointegration test results.

Date: 06/25/15 Time: 22:41

Sample (adjusted): 6/21/2004 6/19/2015

Included observations: 2770 after adjustments

Trend assumption: Linear deterministic trend

Series: D(TY30) D(JLL) D(COLLIERS) D(CBRE)

Lags interval (in first differences): 1 to 1

Unrestricted Cointegration Rank Test (Trace)

\begin{tabular}{ccccc}
\hline $\begin{array}{c}\text { Hypothesized } \\
\text { No. of CE(s) }\end{array}$ & Eigenvalue & Trace Statistic & $\begin{array}{c}0.05 \\
\text { Critical Value }\end{array}$ & Prob. $^{* *}$ \\
\hline None $^{*}$ & 0.390098 & 4920.524 & 47.85613 & 1.0000 \\
At most $1^{*}$ & 0.372259 & 3550.876 & 29.79707 & 1.0000 \\
At most $2^{*}$ & 0.357713 & 2261.089 & 15.49471 & 1.0000 \\
At most $3^{*}$ & 0.311719 & 1034.756 & 3.841466 & 0.0000 \\
\hline
\end{tabular}

Trace test indicates 4 cointegrating eqn(s) at the 0.05 level; ${ }^{\star}$ denotes rejection of the hypothesis at the 0.05 level; ${ }^{* *}$ MacKinnon-Haug-Michelis (1999) $p$-values; Unrestricted Cointegration Rank Test (Maximum Eigenvalue).

\begin{tabular}{ccccc}
\hline $\begin{array}{c}\text { Hypothesized } \\
\text { No. of CE }(\mathrm{s})\end{array}$ & Eigenvalue & $\begin{array}{c}\text { Max-Eigen } \\
\text { Statistic }\end{array}$ & $\begin{array}{c}0.05 \\
\text { Critical Value }\end{array}$ & Prob. $^{* *}$ \\
\hline None $^{*}$ & 0.390098 & 1369.648 & 27.58434 & 0.0000 \\
${\text { At most } 1^{*}}^{*}$ & 0.372259 & 1289.787 & 21.13162 & 1.0000 \\
At most $^{*}$ & 0.357713 & 1226.333 & 14.26460 & 1.0000 \\
At most $^{*}$ & 0.311719 & 1034.756 & 3.841466 & 0.0000 \\
\hline
\end{tabular}

Max-eigenvalue test indicates 4 cointegrating eqn(s) at the 0.05 level; ${ }^{*}$ denotes rejection of the hypothesis at the 0.05 level; ${ }^{* *}$ MacKinnon-Haug-Michelis (1999) $p$-values.

The short run relationship between the variables is given in a Vector Error Correction Model.

$$
\begin{aligned}
\mathrm{D}(\mathrm{TY} 30,2)= & -0.316813087173 *(\mathrm{D}(\mathrm{TY} 30(-1))-0.0550089804477 * \mathrm{D}(\operatorname{JLL}(-1)) \\
& +0.0595267346102 * \mathrm{D}(\operatorname{COLLIERS}(-1))-0.00591325254306 * \mathrm{D}(\operatorname{CBRE}(-1)) \\
& +0.00317645677557)-0.352560713892 * \mathrm{D}(\mathrm{TY} 30(-1), 2) \\
& -0.00644036161784 * \mathrm{D}(\operatorname{JLL}(-1), 2)+0.0125272000199 * \mathrm{D}(\operatorname{COLLIERS}(-1), 2) \\
& +0.00132872566631 * \mathrm{D}(\operatorname{CBRE}(-1), 2)+3.19016263702 \mathrm{e}-05
\end{aligned}
$$




$$
\begin{aligned}
& \mathrm{D}(\mathrm{JLL}, 2)=15.2418724463 *(\mathrm{D}(\mathrm{TY} 30(-1))-0.0550089804477 * \mathrm{D}(\mathrm{JLL}(-1)) \\
& +0.0595267346102 * \mathrm{D}(\operatorname{COLLIERS}(-1))-0.00591325254306 * \mathrm{D}(\operatorname{CBRE}(-1)) \\
& +0.00317645677557)-7.60835455748 * \mathrm{D}(\mathrm{TY} 30(-1), 2) \\
& -0.0783221265831 * \mathrm{D}(\mathrm{JLL}(-1), 2)-0.616002761044 * \mathrm{D}(\operatorname{COLLIERS}(-1), 2) \\
& +0.10807315496 * \mathrm{D}(\operatorname{CBRE}(-1), 2)-0.000107893927196 \\
& \mathrm{D}(\text { COLLIERS, } 2)=-0.227403945333 *(\mathrm{D}(\mathrm{TY} 30(-1))-0.0550089804477 * \mathrm{D}(\mathrm{JLL}(-1)) \\
& +0.0595267346102 * \mathrm{D}(\operatorname{COLLIERS}(-1))-0.00591325254306 * \mathrm{D}(\operatorname{CBRE}(-1)) \\
& +0.00317645677557)+0.0924063457945 * \mathrm{D}(\mathrm{TY} 30(-1), 2) \\
& -0.00303130470218 * \mathrm{D}(\mathrm{JLL}(-1), 2)-0.513549092173 * \mathrm{D}(\operatorname{COLLIERS}(-1), 2) \\
& +0.0203169895612 * \mathrm{D}(\operatorname{CBRE}(-1), 2)-0.000240494727676 \\
& \mathrm{D}(\mathrm{CBRE}, 2)=3.36441259174 *(\mathrm{D}(\mathrm{TY} 30(-1))-0.0550089804477 * \mathrm{D}(\mathrm{JLL}(-1)) \\
& +0.0595267346102 * \mathrm{D}(\operatorname{COLLIERS}(-1))-0.00591325254306 * \mathrm{D}(\operatorname{CBRE}(-1)) \\
& +0.00317645677557)-1.92353822986 * \mathrm{D}(\mathrm{TY} 30(-1), 2) \\
& +0.0959094397997 * \mathrm{D}(\mathrm{JLL}(-1), 2)-0.187324755017 * \mathrm{D}(\operatorname{COLLIERS}(-1), 2) \\
& -0.486121447306 * \mathrm{D}(\operatorname{CBRE}(-1), 2)-0.000125185438099
\end{aligned}
$$

The short run relationship is tested in Granger causality model which is given in Table 5 below.

\section{Discussion}

The major real estate manager companies in the U.S.A are modelled in a Vector Autoregression (VAR) model. The data includes 3 companies and 30 years treasury yield. The model is given to check the interest rate risk.

The variables are first checked to see whether they are stationary with ADF and PP tests. According to the results, test statistics only exceed the critical values when they are differenced. All of the variables are stationary when they are first differenced-I(1).

The lag selection criteria are then given for VAR model. For most degrees of freedom $\operatorname{VAR}(1)$ is used. The model is then checked for autoregressive roots to see whether they are stationary. Since no roots are outside the unit circle, the model is reliable.

The long run relationship is tested for Johansen Cointegration methodology with both Trace and Max-eigenvalue. The results suggest that there are 4 cointegrating vectors. This shows there is a long run relationship between interest rates and stock performance of real estate management firms.

As cointegration is detected, a vector error correction model (VECM) is developed. With this model it is possible to detect short run relationship. Short run relationship between real estate management firms and interest rates are tested with Granger Causality model.

Granger causality is analyzed with 5\% level of significance. Accordingly 30 
Table 5. Granger causality test results.

VEC Granger Causality/Block Exogeneity Wald Tests

Date: 06/25/15 Time: 22:56

Sample: 6/16/2004 6/19/2015

Included observations: 2770

Dependent variable: D(TY30, 2)

\begin{tabular}{|c|c|c|c|}
\hline Excluded & Chi-sq & $\mathrm{df}$ & Prob. \\
\hline $\mathrm{D}(J L L, 2)$ & 54.58057 & 1 & 0.0000 \\
\hline D(COLLIERS, 2) & 16.41853 & 1 & 0.0001 \\
\hline $\mathrm{D}(\mathrm{CBRE}, 2)$ & 0.361264 & 1 & 0.5478 \\
\hline All & 75.18038 & 3 & 0.0000 \\
\hline \multicolumn{4}{|c|}{ Dependent variable: $\mathrm{D}(J L L, 2)$} \\
\hline Excluded & Chi-sq & $\mathrm{df}$ & Prob. \\
\hline D (TY30, 2) & 223.7451 & 1 & 0.0000 \\
\hline D (COLLIERS ,2) & 47.38254 & 1 & 0.0000 \\
\hline $\mathrm{D}$ (CBRE, 2) & 2.852437 & 1 & 0.0912 \\
\hline All & 267.4418 & 3 & 0.0000 \\
\hline \multicolumn{4}{|c|}{ Dependent variable: $\mathrm{D}$ (COLLIERS, 2) } \\
\hline Excluded & Chi-sq & $\mathrm{df}$ & Prob. \\
\hline $\mathrm{D}(\mathrm{TY} 30,2)$ & 0.907468 & 1 & 0.3408 \\
\hline $\mathrm{D}(\mathrm{JLL}, 2)$ & 0.396789 & 1 & 0.5288 \\
\hline $\mathrm{D}$ (CBRE, 2) & 2.771755 & 1 & 0.0959 \\
\hline All & 4.274407 & 3 & 0.2333 \\
\hline \multicolumn{4}{|c|}{ Dependent variable: $\mathrm{D}$ (CBRE, 2) } \\
\hline Excluded & Chi-sq & $\mathrm{df}$ & Prob. \\
\hline $\mathrm{D}(\mathrm{TY} 30,2)$ & 122.3983 & 1 & 0.0000 \\
\hline $\mathrm{D}(\mathrm{JLL}, 2)$ & 123.6427 & 1 & 0.0000 \\
\hline D(COLLIERS, 2) & 37.50118 & 1 & 0.0000 \\
\hline All & 211.8080 & 3 & 0.0000 \\
\hline
\end{tabular}

years treasury yield Granger causes JLL and CBRE. The causality is available also the other way; JLL and CBRE Granger cause TY30.

This indicates that interest rate is an important factor in real estate management firms' stock performance. Therefore interest rate risk should be controlled for stable growth in real estate management industry. The ways to control this risk are also available in the paper, some of which are derivative instruments such as caps, swaps, and collars.

\section{Conclusion}

Real estate is an illiquid and highly leveraged investment that requires the inves- 
tor to apply risk management techniques. The techniques are developing and not widely applied by the market participants.

Real estate leads to cyclical returns, therefore investors can earn stable returns for years, but may also experience sharp falls in property prices. This is also related to risk character of the property. Property in nice location owned by creditable owners is less risky while those to be developed, maintained or distressed properties are more risky. This is often managed by assessing ratings for individual properties in real estate management practice.

Risk management applications are crucial for obtaining stable returns for the company. The portfolio approach is most widely used in the practice. This is done by choosing property with different levels of risks. Typically 400 assets are needed to fully reduce the risks to the systematic level.

The real estate in different locations is preferred to minimize location specific risk. Relatively underdeveloped regions are most of the time more risky but also have higher profit potential. Different segments such as office and retail are also added to diversify the risks. In addition, one might include risky assets such as foreclosure or undeveloped land to increase company potential. The ultimate goal in portfolio management is to minimize idiosyncratic risk component that is due to individual assets.

Insurance is another way of transferring risks. Some risks are very rare but may cause serious damage. These are known as catastrophic risks. This can be in the form of earthquakes or vehicle crush as experienced in 9/11, or other terrorist activity. Fire is also an important risk for real estate and management need to have adequate action plans for these. Most importantly these risks are transferred to insurance companies which are typically reinsured.

Derivatives are widely used in financial markets as a tool to mitigating risks. Derivatives in the real estate market can be through a market or over the counter (OTC). Derivatives in real estate markets can be in the form of forward, futures, options and swaps. The risks to be covered by the real estate derivatives are market risks such as interest rate, inflation, currency risks, and even property price changes.

An investor who will need to borrow in the future will suffer if the interest rates rise and benefit if the interest rates falls. Moreover the loan may be given with variable interest such as LIBOR. So the rise in interest rates may result in a rise in monthly payment which may result in unaffordable payments. If the value of the loan goes above the value of the property, a default may take place. The tools that can be used to mitigate interest rate risk are cap, swap, and collars.

The international nature of the transactions gives the opportunities and risks of borrowing in international markets. This may be also in the form of currency other than the operational currency for the company. If the revenue of the company is in different currency than the loan, then an appreciation in the loan currency may result in loss for the company.

A real estate manager should understand risk management techniques and be 
able to apply necessary precautions for risk to be transferred. A manager should be ready to identify which risks to take and which to transfer. The empirical application given in this paper for interest rate risks in real estate management gives the author better understanding of market dynamics. There are traditional asset based, portfolio, insurance and derivatives techniques that can be applied in real estate risk management.

This research is limited to interest rate risk in real estate industry. For future research, one can work on a more comprehensive data to compute other real estate risks. The research also is limited to portfolios consisting of single real asset segment. It is also possible to research portfolios with mixed real estate segments.

\section{References}

Baumohl, E., \& Vyrost, T. (2010). Stock Market Integration: Granger Causality Testing with Respectto Nonsynchronous Trading Effects. Journal of Economics and Finance, $60,420$.

Buttimer, R., \& Patel K. (2008). Cambridge-UNC Charlotte Symposium 2006 Real Estate Risk Management and Property Derivatives. The Journal of Real Estate Finance and Economics, 36, 1-3.

Donner, S. M. (2010). Risk Management in the Aftermath of Lehmann Brothers-Results from a Survey among German and International Real Estate Investors. Journal of Property Research, 27, 19-21. https://doi.org/10.1080/09599916.2010.499016

Erdinc, H., \& Milla, J. (2009). Analysis of Cointegration in Capital Markets of France, Germany and United Kingdom. Economics \& Business Journal: Inquiries \& Perspectives, $2,114$.

Fabozzi, F. J., Shiller, R., \& Tunaru, R. S. (2009). Hedging Real Estate Risk. The Journal of Portfolio Management Special Real Estate Issue, 35, 92-96.

Fabozzi, F. J., Stanescu, S., \& Tunaru, R. (2013). Commercial Real Estate Risk Management by Derivatives. The Journal of Portfolio Management Special Real Estate Issue, 39, 111-115.

Fisher, J. D. (2005). New Strategies for Commercial Real Estate Investment and Risk Management. The Journal of Portfolio Management Special Issue, 31, 154-157. https://doi.org/10.3905/jpm.2005.593898

Montgomery, M. K. (2005). Rising Rates for Real Estate: Interest Rate Hedge Agreements Can Help. Real Estate Finance, 3-4. 
Submit or recommend next manuscript to SCIRP and we will provide best service for you:

Accepting pre-submission inquiries through Email, Facebook, LinkedIn, Twitter, etc. A wide selection of journals (inclusive of 9 subjects, more than 200 journals)

Providing 24-hour high-quality service

User-friendly online submission system

Fair and swift peer-review system

Efficient typesetting and proofreading procedure

Display of the result of downloads and visits, as well as the number of cited articles Maximum dissemination of your research work

Submit your manuscript at: http://papersubmission.scirp.org/

Or contact jfrm@scirp.org 